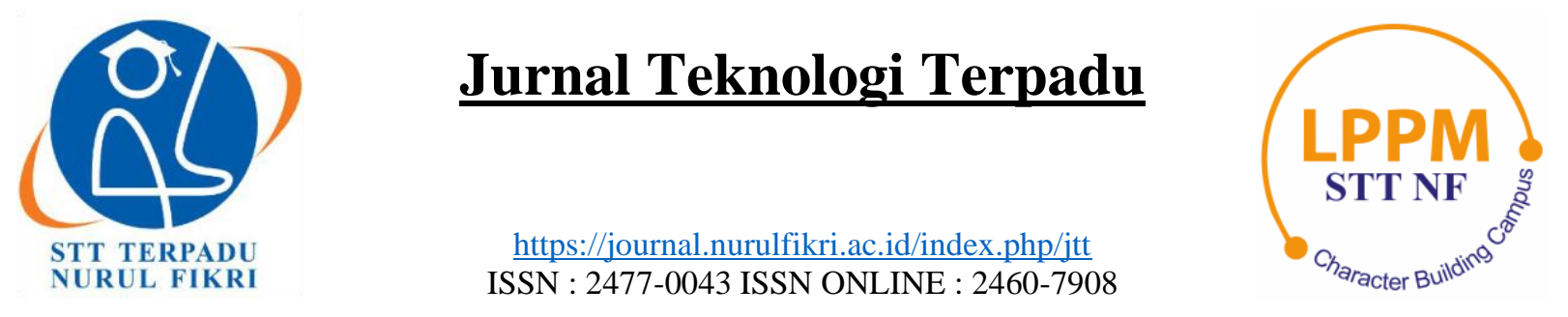

\title{
PEMANFAATAN DATA TRANSAKSI UNTUK DASAR MEMBANGUN STRATEGI BERDASARKAN KARAKTERISTIK PELANGGAN DENGAN ALGORITMA K-MEANS CLUSTERING DAN MODEL RFM
}

\author{
Carudin ${ }^{1}$ \\ ${ }^{1}$ Manajemen Informatika, Sekolah Tinggi Manajemen Informatika dan Komputer Bani Saleh \\ Bekasi Timur, Jawa Barat, Indonesia 17113 \\ carudin@stmik-banisaleh.ac.id
}

\begin{abstract}
Every time there is a transaction process carried out by a customer, that process adds to the data collection in a database. This study uses transaction data to determine customer segmentation and build a strategy based on customer characteristics with the RFM and K-Means model approach. K-Means Clustering is an algorithm that can produce a visual cluster model with the Rapidminer application version 9.9, using the RFM attribute to represent the number of customers from each cluster. The transaction data for the last three years, 2017, 2018, and 2019 with 4,332 transactions, were then managed based on the RFM model resulting in 1898 customers. Furthermore, a cluster analysis carries out using the K-Means algorithm with 319 customers in cluster 1, 314 customers in cluster 2, 316 customers in cluster 3, 317 customers in cluster 4 , 315 customers in cluster 5, and 317 customers in cluster 6. The company can use the results of this study to determine customer characteristics and as a consideration for making a new strategy.
\end{abstract}

Keywords: Clustering, Recency, Frequency, Monetary, K-Means, Customer

\begin{abstract}
Abstrak
Setiap waktu terdapat proses transaksi yang dilakukan oleh pelanggan, proses tersebut menambah koleksi data pada sebuah database. Pada penelitian ini dengan melakukan pemanfaatan data transaksi untuk mengetahui segmentasi pelanggan dan membangun strategi berdasarkan karakteristik pelanggan dengan pendekatan model RFM dan K-Means. K-Means Clustering adalah sebuah algoritma yang dapat menghasilkan suatu model cluster visual dengan aplikasi Rapidminer versi 9.9, dengan menggunakan atribut RFM berfungsi untuk mewakili jumlah pelanggan dari setiap cluster. Dari data transaksi 3 tahun terakhir 2017, 2018, dan 2019 dengan jumlah 4.332 transaksi yang kemudian diolah berdasarkan model RFM menghasilkan 1898 pelanggan. Selanjutnya dilakukan analisis cluster dengan menggunakan algoritma K-Means dengan hasil cluster 1 memliki 319 pelanggan, cluster 2 memiliki 314 pelanggan, cluster 3 memiliki 316 pelanggan, cluster 4 memiliki 317 pelanggan, cluster 5 memiliki 315 pelanggan, dan cluster 6 memiliki 317 pelanggan. Dari hasil penelitian ini dapat dimanfaatkan oleh perusahaan untuk mengetahui karakteristik pelanggan dan sebagai bahan pertimbangan membuat suatu strategi baru.
\end{abstract}

Kata kunci: Clustering, Recency, Frequency, Monetary, K-Means, Pelanggan

\section{PENDAHULUAN}

Perusahaan yang bergerak di bidang retail data transaksi penjualan merupakan data yang sangat berharga di dalam suatu perusahaan. Karena dari data tersebut dapat diolah menjadi beragam informasi yang bisa dimanfaatkan oleh perusahaan, seperti mengetahui prediksi perkembangan perusahaan di masa depan, melihat omset perusahaan, mengetahui karakteristik pelanggan dan lainnya.
Dewasa ini sebagian perusahaan besar mulai memanfaatkan data transaksi untuk diolah dengan menggunakan suatu metode tertentu, sehingga menghasilkan informasi penting yang bisa memprediksi atau membangun suatu strategi bisnis yang bisa memberikan kemajuan pada perusahaan. Salah satunya adalah PT. XYZ yang bergerak di jasa penjualan mobil Jepang, yang mulai memanfaatkan data transaksi penjualan untuk mengelompokan pelanggan berdasarkan karakteristik-karakteristiknya, sehingga dari data yang 
diolah dapat dijadikan acuan untuk membangun suatu strategi pemasaran yang dapat meningkatkan jumlah transaksi penjualan di masa yang akan datang.

Permasalahan yang muncul saat ini adalah dari 3 tahun terakhir ini terjadi penurunan jumlah transaksi, tahun 2017 sebanyak 2092 transaksi dari 1040 pelanggan, tahun 2018 1754 transaksi dari 922 pelanggan, sedangkan jumlah transaksi di tahun 2018 hanya 486 transaksi dari 250 pelanggan, bentuk penurunan jumlah transaksi terlihat di gambar 1 di bawah ini:

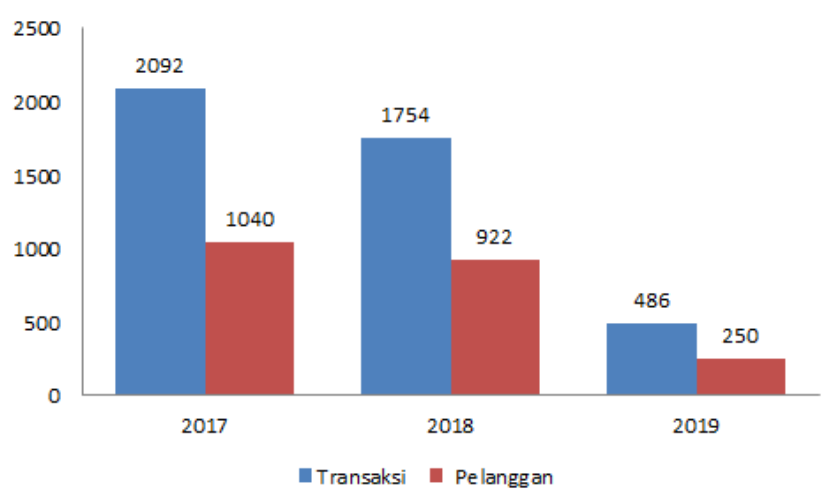

Gambar 1. Grafik Transaksi Penjualan

Dari data transaksi yang disajikan, terlihat jelas semakin banyak pelanggan maka semakin banyak menambah jumlah transaksi. Berdasarkan kondisi dan masalah yang telah dijelaskan di atas, diidentifikasi terkait sebab-sebab yang mempengaruhi penurunan jumlah transaksi. Sehingga perlu dilakukan pengendalian pendekatan terhadap pelanggan dan strategi baru. Pada penelitian ini digunakan data transaksi penjualan 3 tahun terakhir yaitu 2017, 2018 dan 2019 dengan total jumlah transaksi 4332.

Bagaimana memanfaatkan data transaksi dengan model RFM dan mengelompokan berdasarkan karakteristik pelanggan dengan pendekatan algoritma K-Means, sehingga dari hasil clustering dapat dijadikan suatu strategi baru yang tepat dan akurat.

Untuk meningkatkan jumlah transaksi penjualan maka perlu adanya proses pengendalian pendekatan antara perusahaan dan pelanggan, karena hubungan antara perusahaan dan pelanggan merupakan elemen bisnis utama yang menunjang peningkatan transaksi penjualan [1]. Proses pengendalian hubungan antara perusahaan dan pelanggan disebut dengan istilah Customer Relationship Management (CRM). Cakupan konsep CRM meliputi seperangkat metode dan strategi untuk mengembangkan hubungan jangka panjang yang dapat menguntungkan pelanggan dan meningkatkan transaksi penjualan. Menurut [2], CRM dibagi menjadi empat bagian yang berbeda: (1) Identifikasi Pelanggan, (2) Daya Tarik Pelanggan, (3) Retensi Pelanggan, dan (4) Pengembangan Pelanggan.

Segmentasi pelanggan adalah salah satu bagian paling penting dari identifikasi pelanggan dan mencakup mengelompokan seluruh pelanggan sesuai dengan karakteristik pelanggan berdasarkan perilaku pembelian, informasi demografis dan geografis, serta atribut psikografis. Model RFM adalah yang banyak digunakan untuk menentukan segmentasi pelanggan.

\section{Model RFM}

Model RFM dikenal sebagai teknik data mining berdasarkan perilaku yang menggambarkan profil pelanggan dengan memanfaatkan data transaksi dengan mengambil poin recency, frequency, dan monetary [3].

Nilai R, F, dan M dibedakan menjadi lima dengan nilai 1 sampai 5. Nilai R dihasilkan dari waktu transaksi terakhir dengan waktu interval penelitian. Nilai 5 untuk pelanggan yang memiliki waktu transaksi paling dekat dengan waktu penelitian, nilai 1 pelanggan yang memiliki waktu transaksi jauh dengan waktu penelitian. Kemudian nilai F, didapat dari pelanggan yang paling banyak bertransaksi dengan nilai 5, pelanggan yang sedikit bertransaksi diberikan nilai 1. Nilai $M$ didapat dari pelanggan yang memiliki transaksi dengan jumlah uang terbanyak dengan nilai 5. Sedangkan, pelanggan yang melakukan transaksi dan jumlah uang sedikit mempunyai nilai-nilai 1 [4]. Berikut rumus untuk mendapatkan nilai RFM:

$\mathrm{RFM}=(($ Nilai Recency x 100 $)+($ Nilai Frequency $\times 0)+$ Nilai Monetary)

\section{Discretization}

Proses menentukan bobot di setiap fitur data sehingga membentuk data diskrit kategorik. Sehingga dihasilkan dataset indek rasio data dibagi ke dalam 6 bagian dalam pembobotan 6,5,4,3,2,1 dengan konversi 6= "Superstar", 5= "Golden Customer", 4= "Typical Customer", 3= "Occasional Customer", 2= "everyday shopper", 1= "Dormant Customer". Pada bagian dengan nilai rasio terbesar diberi bobot 6 karena menandakan customer superstar [3]. Demikian selanjutnya sampai customer dengan nilai rasio terkecil diberi bobot 1. Hasil yang didapat dari proses pembobotan ini menjadi dataset dasar untuk diolah pada pengolahan berikutnya yakni mengklasifikasikan customer dengan menerapkan metode $\mathrm{K}$-means. Interval data pembobotan ditunjukan pada tabel 1, 2 dan 3 berikut:

Tabel 1. Interval Pembobotan $\mathrm{R}$

\begin{tabular}{ccc}
\hline Recency & $\begin{array}{c}\text { Dari } \\
(\text { Jumlah Hari })\end{array}$ & $\begin{array}{c}\text { Sampai } \\
\text { (Jumlah Hari) }\end{array}$ \\
\hline 6 & 0 & 60 \\
5 & 61 & 120 \\
4 & 121 & 180 \\
3 & 181 & 240 \\
2 & 241 & 300 \\
1 & 301 & $>360$ \\
\hline
\end{tabular}


Tabel 2. Interval Pembobotan F

\begin{tabular}{|c|c|c|}
\hline Frequency & $\begin{array}{c}\text { Dari } \\
\text { (Jumlah Hari) }\end{array}$ & $\begin{array}{c}\text { Sampai } \\
\text { (Jumlah Hari) }\end{array}$ \\
\hline 1 & 1 & 10 \\
\hline 2 & 11 & 20 \\
\hline 3 & 21 & 30 \\
\hline 4 & 31 & 40 \\
\hline 5 & 41 & 50 \\
\hline 6 & 51 & $>60$ \\
\hline
\end{tabular}

Tabel 3. Interval Pembobotan M

\begin{tabular}{ccc}
\hline Monetary & $\begin{array}{c}\text { Dari } \\
(\text { Jumlah Hari })\end{array}$ & $\begin{array}{c}\text { Sampai } \\
(\text { Jumlah Hari })\end{array}$ \\
\hline 1 & 140.000 .000 & 200.000 .000 \\
2 & 200.000 .001 & 260.000 .000 \\
3 & 260.000 .0001 & 310.000 .000 \\
4 & $310 . .000 .001$ & 500.000 .000 \\
5 & 500.000 .001 & 700.000 .000 \\
6 & 700.000 .001 & $>52.780 .050 .000$ \\
\hline
\end{tabular}

\section{Data Mining}

Untuk mendapatkan model yang berguna pada data yang memiliki ukuran yang besar maka perlu menggunakan suatu teknik penambangan data atau dengan istilah data mining [5]. Data yang berasal dari suatu basis data, seperti data transaksi, data warehouse atau data lainnya. Data mining adalah suatu tahapan penting dalam proses KDD (Knowledge Discovery in Database) terpenting berhubungan dengan ekstraksi dan perhitungan model yang diteliti.

\section{Clustering}

Clustering atau disebut juga dengan klasterisasi yaitu suatu metode yang berfungsi mengelompokan objek data menjadi beberapa kelompok, sehingga dari setiap kelompok mempunyai tingkat kesamaan maksimum dan data antar cluster mempunyai tingkat kesamaan minimum [6].

Nilai kemiripan bersumber pada nilai atribut yang melukiskan suatu objek. Clustering juga membuat partisi suatu set objek kedalam kelompok yang dinamakan dengan cluster [7]. Objek yang berada di dalam cluster mempunyai kesamaan karakteristik dengan lainnya dan memiliki perbedaan dengan cluster lainnya. Proses mempartisi data menggunakan suatu algoritma clustering [8].

\section{Algoritma K-Means}

K-Means yaitu algoritma yang memiliki tujuan mengelompokan data dan membentuk beberapa kelompok. Pemprosesan clustering K-Means, dikerjakan oleh sistem komputer yang berfungsi mengelompokan secara otomatis data-data yang menjadi inputan tanpa menentukan target kelompoknya [9]. Pada masing-masing cluster memiliki titik pusat (centroid) yang merepresentasikan cluster tersebut. Proses perhitungan K-Means sebagai berikut [10]:

- Menetapkan nilai k sebagai jumlah cluster yang dibuat.

- Menetapkan nilai centroid pertama atau titik pusat cluster. Proses ini menentukan nilai centroid dengan cara random, akan tetapi untuk proses selanjutnya menggunakan rumus berikut:

$\underline{v_{i j}}=\frac{1}{N_{i}} \sum_{k=0}^{N i} X_{k j}$

Dimana :

$V_{i j}=$ Centroid ke-I untuk variable ke-j

$N_{i}=$ Jumlah cluster ke-i

$i, k=$ indeks dari cluster

$j=$ indeks dari variabel

$X_{k j}=$ nilai data ke-k di cluster untuk variable ke-j

- Jarak centroid dengan titik tiap-tiap objek, bisa dihitung dengan menerapkan rumus Euclidean Distance (nilai kedekatan) berikut:

$D\left(x_{i}, y_{j}, z_{k}\right)=\sqrt{\left(x_{i 1}-m_{j 1}\right)^{2}+\left(x_{i 2}-m_{j 2}\right)^{2}+\left(x_{i 3}-m_{j 3}\right)^{2}}$

- Mencari jarak minimum antar cluster

$a_{k}=d_{k}=\min \left\{D\left(X_{k}, C_{i}\right), \mathrm{i}=1,2,3,4,5,6 k=1,2, . ., \mathrm{n}\right\}$

Keterangan:

$a_{k}=d_{k}=$ Jarak minimum tiap cluster

$X_{k}=$ Keanggotaan data ke- $k$

$C_{i}=$ Nilai centroid cluster ke-i

- Mencari nilai centroid baru

$$
\underline{v_{i j}}=\frac{1}{N_{i}} \sum_{k=0}^{N i} X_{k j}
$$

Dimana :

$v_{i j}=$ centroid rata-rata cluster ke-i untuk variabel ke-j

$\overline{N_{i}}=$ jumlah anggota cluster $\mathrm{ke}-\mathrm{I} \mathrm{i}, \mathrm{k}=$ indeks dari cluster

$j \quad=$ indeks dari variabel

$X_{k j}=$ nilai data ke-k variabel ke-j dalam cluster tersebut.

- Jika hasil perhitungan pada iterasi berikutnya tidak ada perubahan pada anggota cluster, maka perhitungan dinyatakan selesai.

Beberapa penelitian sebelumnya menggunakan model RFM untuk menganalisis data penjualan seperti yang dilakukan oleh Tavakoli, Molavi dkk. di perusahaan Digikala, perusahaan E-Commerce terbesar di Timur Tengah, dengan membandingkan model RFM dan model 
Customer Quantile dari hasil perbandingan diterapkan ke dalam bentuk promosi melalui media SMS sesuai dengan strategi menunjukan bahwa model segmentasi RFM mampu meningkatkan jumlah pembelian [1]

Penelitian oleh Ananthi Sheshasaayee dan Logeshwari dari data transaksi pelanggan dilakukan konversi kedalam model RFM kemudian dilakukan diskritisasi dan dikelompokan menjadi 2, satu cluster 0 dikategorikan sebagai pelanggan yang memiliki frekuensi pembelian tinggi sehingga kelompok ini hanya membutuhkan sedikit konsentrasi dan loyalitas, sedang cluster 1 memiliki frekuensi pembelian renda sehingga mereka membutuhkan lebih banyak penawaran dan pengingat melalui iklan [11].

Penelitian oleh Ina Maryani, Dwiza Riana dkk, melakukan analisis segmentasi pelanggan dari transaksi pembelian isi ulang pulsa dengan model RFM dan teknik clustering $K$ Means, dari 82.648 transaksi diolah berdasarkan Model RFM menghasilkan 102 Nasabah, kemudian dilakukan

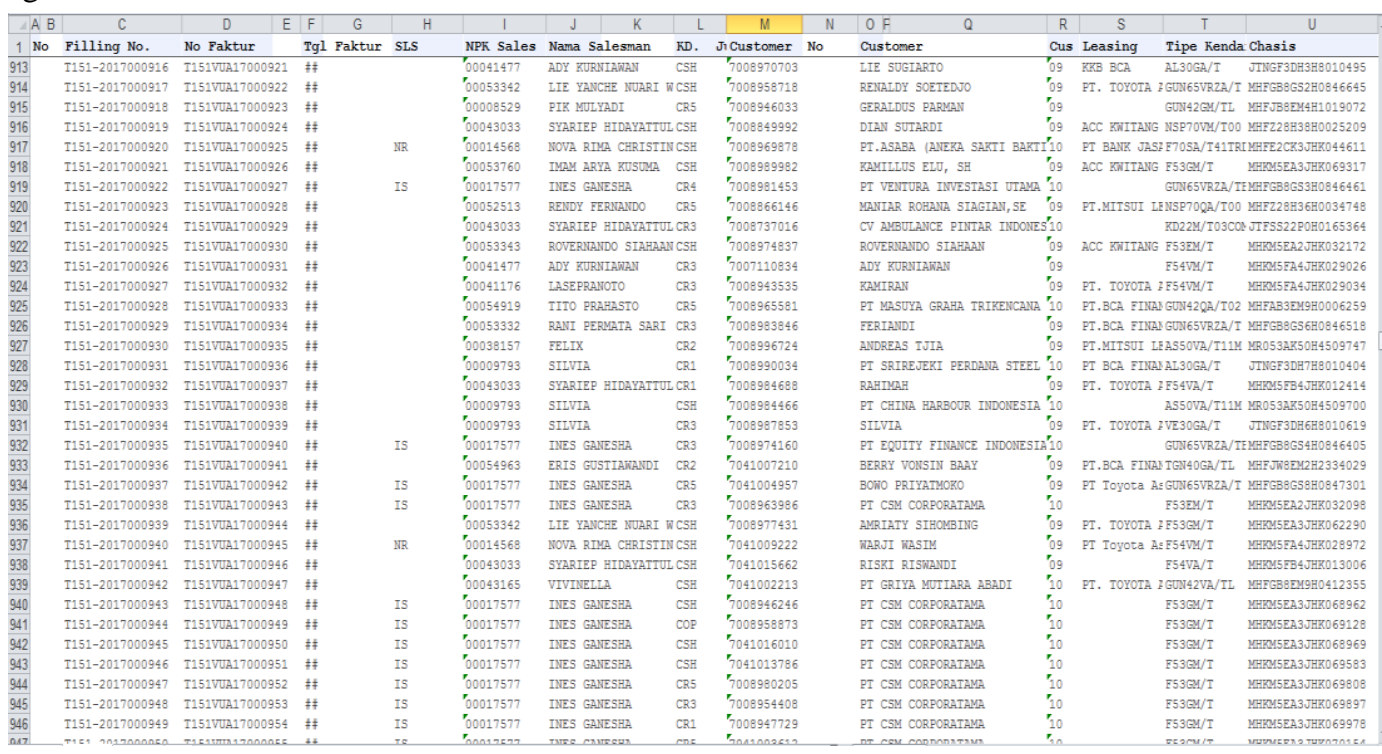

Gambar 2. Dataset Transaksi Penjualan
Pada pengumpulan data ini dengan melakukan studi pustaka, membaca dan mempelajari jurnal-jurnal yang berhubungan dengan topik penelitian, melakukan observasi ke objek penelitian, melakukan wawancara dengan bagian penjualan, melihat dan mempelajari data transaksi penjualan. Pada proses ini bertujuan untuk menghasilkan data dan informasi yang selengkap-lengkapnya terkait sistem yang berjalan saat ini.

b. Instrumen Penelitian

Pada instrumen penelitian ini mengadopsi dan memodifikasi pada penelitian sebelumnya yang dilakukan oleh [1] dan [4]. Data transaksi penjualan 3 tahun 2017, 2018 dan 2019 dengan jumlah transaksi 4332 penjualan, terlihat data transaksi penjualan pada gambar 1 berikut: klasterisasi kedalam 2 cluster dengan hasil 63 pelanggan di cluster 1 dan 39 pelanggan di cluster 2 [4].

Pada penelitian ini terdapat perbedaan dari penelitianpenelitian sebelumnya, pada penelitian oleh Ina Maryani dkk [4] dan penelitian oleh Ananthi Sheshasaayee dkk [11], pengelompokan segmentasi hanya menggunakan 2 cluster saja, sedangkan pada penelitian saat ini menggunakan 6 cluster mengacu pada teori karakteristik pelanggan, penentuan nilai centroid awal dilakukan secara acak sehingga menghasilkan performa clustering yang baik.

\section{METODE PENELITIAN}

Tahapan ini berisi penjelasan tentang jenis penelitian/ desain penelitian.

\subsection{Metode Pengumpulan Data, Instrumen Penelitian dan Metode Pengujian}

a. Metode Pengumpulan Data
Variabel-variabel instrumen yang akan digunakan dalam model RFM, terlihat pada tabel 1 berikut:

Tabel 4. Daftar Instrumen Penelitian

\begin{tabular}{ll}
\hline \multicolumn{1}{c}{ Variabel } & \multicolumn{1}{c}{ Keterangan } \\
\hline Recency & $\begin{array}{l}\text { Perbandingan waktu transaksi } \\
\text { terakhir dengan waktu penelitian. } \\
\text { Apabila jarak semakin dengan } \\
\text { dengan waktu penelitian maka nilai }\end{array}$ \\
& R semakin besar. \\
& Jumlah banyaknya transaksi oleh \\
pelanggan pada suatu waktu tertentu. & \\
& Jika jumlah transaksi semakin \\
banyak, nilai F semakin besar.
\end{tabular}




\begin{tabular}{ll}
\hline Variabel & Keterangan \\
\hline & semakin besar. \\
\hline
\end{tabular}

c. Metode Pengujian

Pada tahap ini dilakukan pengujian Cluster Distance Performance dengan menggunakan Rapidminer [12]. Dimana pengujian ini akan menghitung kinerja jarak antar cluster, hasil pengujian menunjukan nilai lebih kecil jarak antar cluster maka dinyatakan baik [13].

\subsection{Tahapan penelitian}

Pada tahapan penelitian dituangkan dalam bentuk bagan alur, terlihat pada gambar 3 :

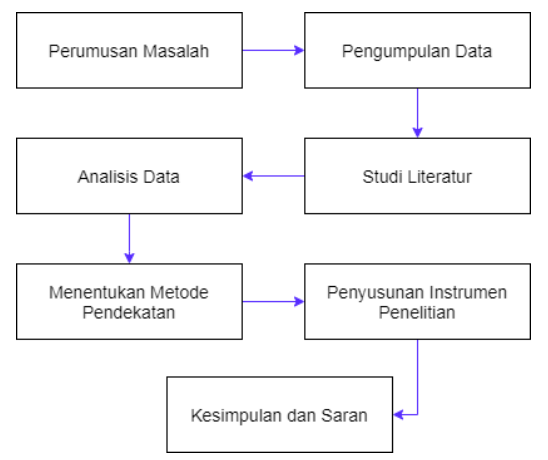

Gambar 3. Tahapan Penelitian

Pada tahapan penelitian dapat dijelaskan sebagai berikut:

1. Perumusan Masalah

Peneliti melakukan pencarian pokok permasalahan yang akan diteliti.

2. Pengumpulan Data

Pada pengumpulan data peneliti menggali data dan informasi dari berbagai sumber, dari teknik wawancara sampai dokumen pendukung lainnya seperti data transaksi penjualan.

3. Studi Literatur

Peneliti melakukan pencarian teori dan model dari berbagai sumber, seperti jurnal, buku, hasil karya ilmiah dan artikel lainnya yang memiliki kesamaan dalam pembahasan.

4. Analisis Data

Pada tahapan analisis data dapat dihasilkan dari penggalian data dan informasi. Dari hasil penggalian data dan informasi kemudian akan dijadikan bahan untuk menganalisis sesuai permasalahaan yang ada.

5. Penyusunan Instrumen Penelitian Instrumen penelitian diadopsi dari hasil penelitian sebelumnya yang telah dilakukan oleh [4] dan [1]

6. Menentukan Metode Pendekatan

Peneliti menentukan metode pendekatan yang cocok untuk bisa memecahkan permasalahan yang ada, yaitu menggunakan Model RFM dan K-Means Clustering

7. Kesimpulan dan Saran

Tahapan terakhir penelitian memberikan kesimpulan dan saran dari hasil penelitian yang dilakukan.

\section{HASIL DAN PEMBAHASAN}

Berikut adalah hasil dan pembahasan dari penelitian, dituangkan dalam bentuk diagram terlihat pada gambar 4 berikut:

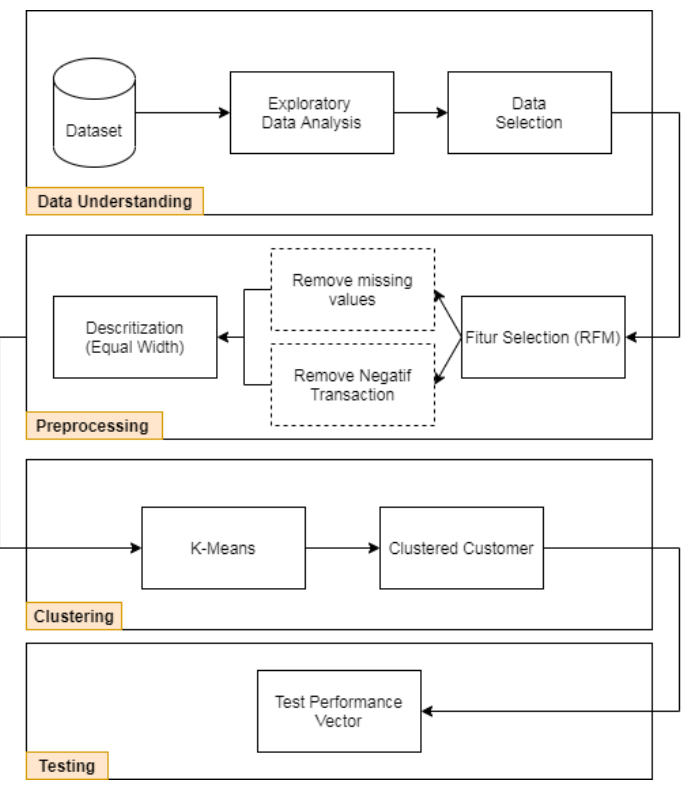

Gambar 4. Alur Penelitian

Berikut adalah rincian penjelasan setiap alur prosesnya.

\section{Data Understanding (Pemahaman Data)}

Dataset yang digunakan dalam penelitian ini adalah dataset transaksi penjualan tahun 2017, 2018, dan 2019 pada PT. XYZ. Dengan jumlah transaksi penjualan 4332.

\section{Preprocessing}

Dari hasil penggalian data, terdapat data transaksi dengan bentuk struktur seperti pada tabel 2 berikut:

Tabel 5. Struktur Tabel Transaksi

\begin{tabular}{cll}
\hline No & Nama Filed & \multicolumn{1}{c}{ Keterangan } \\
\hline 1 & $\begin{array}{l}\text { TglTransaksi } \\
\text { Customer }\end{array}$ & $\begin{array}{l}\text { Tanggal pada saat customer } \\
\text { melakukan pembelian }\end{array}$ \\
2 & NoFaktur & Nomor urut transaksi \\
3 & KdCustomer & $\begin{array}{l}\text { Kode Customer yang melakukan } \\
\text { transaksi }\end{array}$ \\
4 & NamaCustomer & $\begin{array}{l}\text { Nama } \\
\text { melakukan transaksi pembelian }\end{array}$ \\
5 & TypeKendaraan & $\begin{array}{l}\text { Kode setiap kendaraan yang } \\
\text { dibeli customer }\end{array}$ \\
6 & KaroseriSpec & Nama kendaraan dan jenisnya \\
7 & Qty & Jumlah beli \\
8 & HargaUnit & Harga satuan kendaraan \\
9 & TotalHarga & Jumlah harga hasil kali Qty dan \\
& & Harga Unit
\end{tabular}


Selanjutnya mereduksi filed atau menghapus filed yang tidak digunakan dalam model RFM, sehingga terbentuk hasil yang terlihat pada tabel 3 berikut:

Tabel 6. Hasil Reduksi Filed

\begin{tabular}{lll}
\hline No & Nama Filed & \multicolumn{1}{c}{ Keterangan } \\
\hline 1 & TglTransaksi & $\begin{array}{l}\text { Tanggal pada saat customer } \\
\text { melakukan pembelian }\end{array}$ \\
2 & KdCustomer & $\begin{array}{l}\text { Kode customer yang } \\
\text { melakukan transaksi }\end{array}$ \\
3 & NamaCustomer & $\begin{array}{l}\text { Nama customer yang } \\
\text { melakukan transaksi }\end{array}$ \\
& TotalHarga & Jumlah harga kendaraan \\
& & yang dibeli \\
\hline
\end{tabular}

Berikut adalah bentuk data transaksi yang telah dilakukan reduksi filed atau penghapusan filed yang tidak dibutuhkan, terlihat pada tabel 7 berikut:

Tabel 7. Hasil Reduksi Data Transaksi

\begin{tabular}{|c|c|c|c|}
\hline $\begin{array}{c}\text { Tgl } \\
\text { Transaksi }\end{array}$ & Kd Customer & $\begin{array}{c}\text { Nama } \\
\text { Customer }\end{array}$ & Total Harga \\
\hline 2019-01-02 & 2100004679 & $\begin{array}{l}\text { PT. SERASI } \\
\text { AUTORAYA }\end{array}$ & 227450000 \\
\hline 2019-01-02 & 5300024425 & $\begin{array}{l}\text { ANDRI } \\
\text { JAUHARI }\end{array}$ & 176450000 \\
\hline 2019-01-03 & 5300127855 & $\begin{array}{l}\text { PT } \quad \text { CSM } \\
\text { CORPORATA } \\
\text { MA }\end{array}$ & 162000000 \\
\hline 2019-01-04 & 5301143940 & $\begin{array}{l}\text { PT.TIMAS } \\
\text { SUPLINDO }\end{array}$ & 191100000 \\
\hline 2019-01-07 & 5302006658 & $\begin{array}{l}\text { AJB BUMI } \\
\text { PUTERA } 1912\end{array}$ & 329000000 \\
\hline .. & $\cdots$ & $\cdots$ & $\ldots$ \\
\hline 2019-04-30 & 7042449321 & $\begin{array}{l}\text { BUDI } \\
\text { HARTONO }\end{array}$ & 452250000 \\
\hline
\end{tabular}

Selanjutnya dilakukan transformasi data kedalam model RFM, yang dituangkan pada tabel 5 berikut:

Tabel 8. Hasil Transformasi Data ke dalam Model RFM

\begin{tabular}{llllc}
\hline Kd Customer & \multicolumn{1}{c}{$\begin{array}{c}\text { Nama } \\
\text { Customer }\end{array}$} & $\boldsymbol{R}$ & $\boldsymbol{F}$ & $\boldsymbol{M}$ \\
\hline 2100004679 & $\begin{array}{l}\text { PT. SERASI } \\
\text { AUTORAYA }\end{array}$ & 557 & 10 & 6493400000 \\
5300024425 & $\begin{array}{l}\text { ANDRI } \\
\text { JAUHARI }\end{array}$ & 818 & 1 & 297800000 \\
5300127855 & $\begin{array}{l}\text { PT CORPORATA } \\
\text { CORP }\end{array}$ & & & \\
& $\begin{array}{l}\text { MA } \\
5301143940\end{array}$ & & & \\
& PT.TIMAS & 802 & 4 & 4047000000
\end{tabular}

\begin{tabular}{|c|c|c|c|c|}
\hline Kd Customer & $\begin{array}{c}\text { Nama } \\
\text { Customer }\end{array}$ & $\bar{R}$ & $\bar{F}$ & $\bar{M}$ \\
\hline & SUPLINDO & & & \\
\hline 5302006658 & $\begin{array}{ll}\text { AJB } & \text { BUMI } \\
\text { PUTERA } & 1912\end{array}$ & $\begin{array}{l}102 \\
0\end{array}$ & 1 & 1112600000 \\
\hline$\cdots$ & $\ldots$ & $\ldots$ & .. & $\ldots$. \\
\hline 7042449321 & $\begin{array}{l}\text { BUDI } \\
\text { HARTONO }\end{array}$ & 1 & 245 & 191.100 .000 \\
\hline
\end{tabular}

Berikutnya dari hasil proses reduksi dilakukan proses Descritization (Equal Width), terlihat pada tabel 9:

Tabel 9. Hasil Descrititation

\begin{tabular}{|c|c|c|c|c|c|}
\hline No & Kd Customer & Nama Customer & $R$ & $F$ & $M$ \\
\hline 1 & 2100004679 & $\begin{array}{l}\text { PT. SERASI } \\
\text { AUTORAYA }\end{array}$ & 1 & 2 & 5 \\
\hline 2 & 5300024425 & $\begin{array}{l}\text { ANDRI } \\
\text { JAUHARI }\end{array}$ & 1 & 1 & 4 \\
\hline 3 & 5300127855 & $\begin{array}{l}\text { PT } \quad \text { CSM } \\
\text { CORPORATAM } \\
\text { A }\end{array}$ & 2 & 5 & 5 \\
\hline 4 & 5301143940 & $\begin{array}{l}\text { PT.TIMAS } \\
\text { SUPLINDO }\end{array}$ & 1 & 2 & 5 \\
\hline 5 & 5302006658 & $\begin{array}{l}\text { AJB } \\
\text { PUTERA } 1912\end{array}$ & 1 & 1 & 5 \\
\hline .. & $\cdots$ & $\cdots$ & $\cdots$ &.$\cdot$ & $\cdots$ \\
\hline 4332 & 7042449321 & $\begin{array}{l}\text { BUDI } \\
\text { HARTONO }\end{array}$ & 2 & 1 & 2 \\
\hline
\end{tabular}

\section{Clustering}

Tahapan ini menggunakan algoritma K-means Clustering dengan aplikasi Rapidminer, berikut hasil clustering terlihat pada gambar 5:

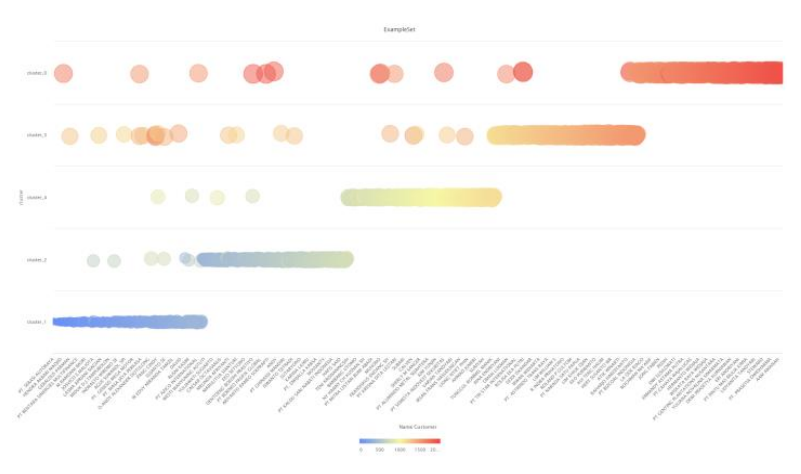

Gambar 5. Hasil Klustering K-Means

Hasil cluster model kemudian dimasukan kedalam tabel kelas pelanggan, untuk mengelompokan pelanggan ke dalam 6 Cluster, yaitu C5 = Dormant Customer, C4 = Everyday shopper, $\mathrm{C} 3=$ Occasional Customer, $\mathrm{C} 2=$ Typical Customer, $\mathrm{C} 1=$ Golden Customer, $\mathrm{C} 0=$ 
Superstar, sehingga menghasilkan presentasi kelompok seperti pada gambar 10 berikut ini:

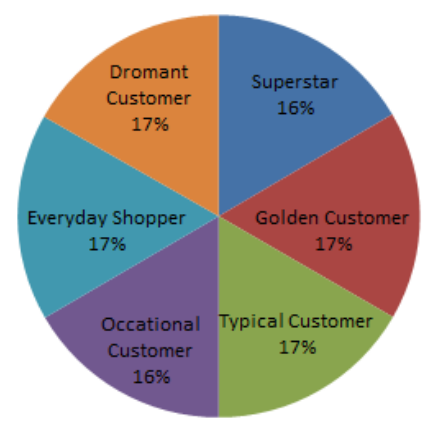

Gambar 6. Persentase Berdasarkan Kelas Pelanggan

Tabel 10. Kelas Pelanggan

\begin{tabular}{|c|c|c|}
\hline Kelas Pelanggan & $\begin{array}{c}\text { Jumlah } \\
\text { Pelanggan }\end{array}$ & Keterangan \\
\hline Superstar & 314 & $\begin{array}{l}\text { - } \text { Pelanggan memiliki loyalitas } \\
\text { yang tinggi. } \\
\text { - Pelanggan } \\
\text { mengeluarkan banyak uang } \\
\text { dalam melakukan transaksi. } \\
\text { - Pelanggan yang memiliki } \\
\text { kedekatan rentang waktu } \\
\text { dengan penelitian } \\
\text { - Memiliki jumlah transaksi } \\
\text { paling banyak. }\end{array}$ \\
\hline Golden Customer & 319 & $\begin{array}{l}\text { - } \text { Pelanggan } \\
\text { mengeluarkan banyak uang } \\
\text { tertinggi kedua } \\
\text { - Memiliki kedekatan dengan } \\
\text { rentang waktu dengan } \\
\text { penelitian } \\
\text { - Memiliki nilai rata-rata } \\
\text { transaksi }\end{array}$ \\
\hline Typical Customer & 316 & $\begin{array}{l}\text { Memiliki nilai rata-rata uang } \\
\text { dan rata-rata transaksi }\end{array}$ \\
\hline $\begin{array}{l}\text { Occasional } \\
\text { Customer }\end{array}$ & 315 & $\begin{array}{l}\text { - Memiliki jumlah uang rendah } \\
\text { - Memiliki nilai rentang waktu } \\
\text { paling rendah } \\
\text { - Memiliki transaksi tertinggi }\end{array}$ \\
\hline Everyday shopper & 316 & $\begin{array}{l}\text { - Mempunyai peningkatan } \\
\text { pada jumlah transaksi } \\
\text { - Memiliki nilai transaksi } \\
\text { rendah } \\
\text { - Memiliki jumlah uang sedang } \\
\text { sampai dengan rendah }\end{array}$ \\
\hline $\begin{array}{l}\text { Dormant } \\
\text { Customer }\end{array}$ & 318 & $\begin{array}{l}\text { - Memiliki jumlah transaksi } \\
\text { dan jumlah uang yang paling } \\
\text { rendah } \\
\text { - Nilai rentang waktu yang } \\
\text { paling rendah }\end{array}$ \\
\hline
\end{tabular}

\section{Testing (Test Performance Cluster)}

Berikut gambar 7. grafik hasil uji performa vector :

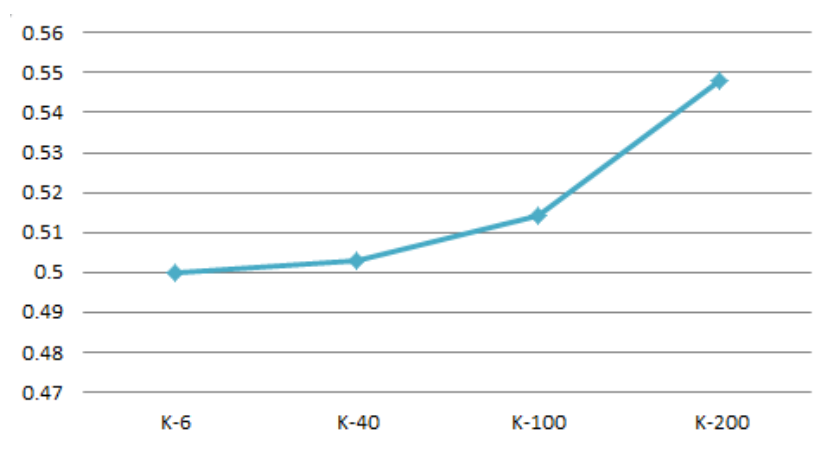

Gambar 7. Hasil Uji Performa

Hasil uji kinerja cluster menunjukan bahwa pengelompokan dengan menggunakan 6 cluster menghasilkan nilai Davies Bouldin: 0.500, sedangkan pengelompokan dengan menggunakan lebih dari 40 cluster menghasilkan nilai Davies Bouldin: > 0.500. sehingga dapat disimpulkan bahwa dengan menggunakan 6 cluster memiliki kinerja cluster terbaik dengan menggunakan jumlah data 1898 .

\section{KESIMPULAN}

Berdasarkan uraian sebelumnya dan hasil dari simulasi data, maka pada penelitian ini dapat ditarik kesimpulan diantaranya:

Dari hasil penggalian data penjualan tahun 2017, 2018, dan 2019 dihasilkan segmentasi pelanggan berdasarkan kelas pelanggan, Dormant Customer sebanyak 318, Everyday Shopper sebanyak 316, Occasional Customer sebanyak 315, Typical Customer sebanyak 316, Golden Customer sebanyak 319 dan Super Start sebanyak 314.

\section{DAFTAR PUSTAKA}

[1] M. Tavakoli, M. Molavi, V. Masoumi, M. Mobini, S. Etemad, and R. Rahmani, "Customer Segmentation and Strategy Development Based on User Behavior Analysis, RFM Model and Data Mining Techniques: A Case Study," Proc. - 2018 IEEE 15th Int. Conf. E-bus. Eng. ICEBE 2018, pp. 119-126, 2018, doi: 10.1109/ICEBE.2018.00027.

[2] D. S. AH Kracklauer, DQ Mills, "Customer Management as The Origin of Collaborative Customer Relationship Management," 2004.

[3] B. E. Adiana, I. Soesanti, and A. E. Permanasari, "Analisis Segmentasi Pelanggan Menggunakan Kombinasi RFM Model dan Teknik Clustering," J. Terap. Teknol. Inf., vol. 2, no. 1, pp. 23-32, 2018, doi: 10.21460/jutei.2018.21.76.

[4] I. Maryani, D. Riana, R. D. Astuti, A. Ishaq, Sutrisno, and E. A. Pratama, "Customer Segmentation Based on RFM Model and Clustering Techniques with K-Means Algorithm," Proc. 3rd Int. Conf. Informatics Comput. ICIC 2018, pp. 1-6, 2018, doi: 10.1109/IAC.2018.8780570.

[5] A. A. Fajrin, A. Maulana, T. Informatika, U. P. 
Batam, and J. R. Soeprapto, "Penerapan Data Mining untuk Analisis Pola Pembelian Konsumen dengan Algoritma Fp-Growth pada Data Transaksi Penjualan Spare Part Motor," J. Ilmu Komput. Vol. 05, No.01, vol. 05, no. 01, pp. 27-36, 2018.

[6] C. D. Rumiarti, I. Budi, P. Studi, M. Teknologi, F. I. Komputer, and U. Indonesia, "Segmentasi Pelanggan pada Customer Relationship Management di Perusahaan Ritel: Studi Kasus Pt Gramedia Asri Media," Jurnal Sistem Informasi, Vol. 13, No. 1, pp. 1-10, 2017. DOI : http://dx.doi.org/10.21609/jsi.v13i1.525

[7] Sudriyanto, “Clustering Loyalitas Pelanggan dengan Metode RFM (Recenty, Frequency, Monetary) dan Fuzzy C-Means," Pros. SNATIF Ke-4, pp. 815-822, 2017.

[8] M. L. Sibuea and A. Safta, "Pemetaan Siswa Berprestasi menggunakan Metode K-Means Clustring," Jurteksi, vol. 4, no. 1, pp. 85-92, 2017, doi: 10.33330/jurteksi.v4i1.28.

[9] F. Hadi, M. Mustakim, D. O. Rahmadia, F. H. Nugraha, N. P. Bulan, and S. Monalisa, "Penerapan K-Means Clustering berdasarkan RFM Mofek sebagai Pemetaan dan Pendukung Strategi
Pengelolaan Pelanggan (Studi Kasus: PT. Herbal Penawar Alwahidah Indonesia Pekanbaru)," $J$. Sains dan Teknol. Ind., vol. 15, no. 1, pp. 69-76, 2017.

[10] M. Reza and T. Akter, "Segmentation of Mobile Customers using Data Mining Techniques," IJERT Vol.7 Issue 10, vol. 7, no. 10, pp. 251-255, 2018.

[11] A. Sheshasaayee and L. Logeshwari, "Implementation of Clustering Technique Based RFM Analysis for Customer Behaviour in Online Transactions," Proc. 2nd Int. Conf. Trends Electron. Informatics, ICOEI 2018, no. Icoei, pp. 1166-1170, 2018 10.1109/ICOEI.2018.8553873.

[12] R. Gustriansyah, N. Suhandi, and F. Antony, "Clustering Optimization in RFM Analysis Based On K-Means," Indones. J. Electr. Eng. Comput. Sci., Vol. 18, No. 1, pp. 470-477, 2019. doi: 10.11591/ijeecs.v18.i1.pp470-477.

[13] T. A. A. Sandi, M. Raharjo, J. L. Putra, and R. Ridwan, "Clustering Kesetiaan Pelanggan dengan Model RFM (Recency, Frequency, Monetary) dan K-Means," J. Pilar Nusa Mandiri, vol. 14, no. 2, p. 239, 2018. doi: 10.33480/pilar.v14i2.950. 